Економічні науки: збірник наукових прачь Луиького національного технічного університету. Серія "Регіональна економіка". Випуск 17 (67). Редкол.: відп. ред. к.е.н., професор І.В. Кривов’язюк. Луиьк: ІВВ Луцького НТУ, 2020. 348 с.

УДК 332.3:502(477)

Кощій О.В., д.е.н., професор

Стрижеус Л.В., к.е.н., доцент

Луцький національний технічний університет

\title{
ЗАБЕЗПЕЧЕНІСТЬ ПРИРОДНИМИ РЕСУРСАМИ ТА ЕФЕКТИВНІСТЬ ЇХ ВИКОРИСТАННЯ В УКРАЇНІ
}

В статті розглянуто питання підвищення ефективності використання природних ресурсів в Україні. Виявлено, що національна економіка займає доволі високі позиції за рівнем забезпеченості природними ресурсами та низькі позиції за індексом управління ресурсами. Розроблено пропозиції щодо підвищення ефективності використання природних ресурсів в Україні. 
Економічні науки: збірник наукових прачь Луиького національного технічного університету. Серія "Регіональна економіка". Випуск 17 (67). Редкол.: відп. ред. к.е.н., професор І.В. Кривов’язюк. Луцьк: ІВВ Луцького НТУ, 2020. 348 с.

Ключові слова: природні ресурси, економічний розвиток, індекс управління ресурсами, Україна, голландська хвороба, прокляття природних ресурсів.

\section{Koschiy O., Stryzheus L. \\ SECURITY OF NATURAL RESOURCES AND EFFICIENCY OF THEIR USE IN UKRAINE}

The article considers the growing needs of the world in natural resources. The rating of the countries of the world on the level of production of natural resources is considered. It was found that Ukraine occupies a fairly high position in the world in terms of natural resources. At present, Ukraine is one of the ten countries in the world that are leaders in the production of gallium, germanium, kaolin, titanium, iron, manganese, uranium and graphite. At the same time, the national economy is characterized by low quality management of natural resources. This is evidenced by the low value of the resource management index in Ukraine. The results of the evaluation of the resource management index show that in Ukraine there are both positive and problematic aspects in the field of resource management. The results indicate that natural resources can benefit the population of Ukraine, but the final benefits are unlikely to be significant.

The low quality of resource management in Ukraine has a negative impact on the economic development of the national economy, its competitiveness in the world market, living standards. It is revealed that the national economy is characterized by the presence of a number of problems in the field of natural resources management: the lack of a perfect regulatory framework that would properly regulate the process of nature management; inadequate incentives for the rational use of the resource potential of the national economy; lack of compliance of current legislation in the field of nature management with international standards; dominance of production of goods with a low level of value added; high share in the structure of exports of goods with low value added, etc. Proposals have been developed to improve resource management in the national economy, which will contribute to its economic growth, increase competitiveness in the world market, increase the welfare of Ukrainians.

Key words: natural resources, economic development, resource management index, Ukraine, dutch disease, curse of natural resources.

Кощий О.В., Стрижеус Л.В.

\section{ОБЕСПЕЧЕННОСТЬ ПРИРОДНЫМИ РЕСУРСАМИ И ЭФФЕКТИВНОСТЬ ИХ ИСПОЛЬЗОВАНИЯ В УКРАИНЕ}

В статье рассмотрены вопросы повышения эффективности использования природных ресурсов в Украине. Выявлено, что национальная 
Економічні науки: збірник наукових прачь Луиького національного технічного університету. Серія "Регіональна економіка". Випуск 17 (67). Редкол.: відп. ред. к.е.н., професор І.В. Кривов’язюк. Луцьк: ІВВ Луцького НТУ, 2020. 348 с.

экономика занимает довольно высокие позиции по уровню обеспеченности природными ресурсами и низкие позиции по индексу управления ресурсами. Разработаны предложения по повышению эффективности использования природных ресурсов в Украине.

Ключевые слова: природные ресурсы, экономическое развитие, индекс управления ресурсами, Украина, голландская болезнь, проклятие природных ресурсов.

Постановка проблеми у загальному вигляді і її зв'язок 3 важливими науковими та практичними завданнями. Будьяка країна для успішного економічного розвитку потребує ресурсів. Без них неможливо розвиватися, належним чином організувати виробництво товарів та послуг, задовольнити потреби населення тощо. У зв'язку 3 цим багато науковців приділяють увагу вивченню питання забезпечення країн природними ресурсами та їх впливу на економічний розвиток останніх.

Аналіз останніх досліджень, у яких започатковано вирішення проблеми. Проблемі забезпечення та підвищення ефективності використання природних ресурсів присвятили праці Голян В., Крупеніна О., Кущ О., Мартинюк I., Прудникова О., Червяков І., Шалаєва А. тощо.

Цілі статті. Ціль статті полягає у пошуку шляхів підвищення ефективності використання природних ресурсів в Україні.

Виклад основного матеріалу дослідження 3 повним обгрунтуванням отриманих наукових результатів. Проблема задоволення потреб суспільства в умовах обмеженості ресурсів нині постає 3 особливою актуальністю. Для світової економіки притаманна тенденція до постійного зростання обсягу споживання різноманітних ресурсів, в т.ч. і мінеральних. Так за останні 30 років (з 1988 р. по 2018 р.) світовий обсяг виробництва корисних копалин зріс в 1,7 рази: 3 10,4 млрд тонн до 17,7 млрд тонн. Це було зумовлено збільшенням попиту на мінеральну сировину і метали. В першу чергу подібне зростання попиту на сировинні ресурси відбулося за рахунок країн, що розвиваються (Китаю, Індії). 
Економічні науки: збірник наукових прачь Луиького національного технічного університету. Серія "Регіональна економіка". Випуск 17 (67). Редкол.: відп. ред. к.е.н., професор І.В. Кривов’язюк. Луцьк: ІВВ Луцького НТУ, 2020. 348 с.

Рейтинг 20 найбільших країн світу за обсягами виробництва корисних копалин представлено в таблиці 1 [1].

Таблиця 1

Рейтинг країн світу за обсягами виробництва корисних копалин

\begin{tabular}{|l|l|c|c|}
\hline № & \multicolumn{1}{|c|}{ Країни } & $\begin{array}{c}\text { Обсяг } \\
\text { виробництва за } \\
2018 \text { р., млн. тонн }\end{array}$ & $\begin{array}{c}\text { Обсяг виробництва у } \\
\text { вартісному } \\
\text { вираженні, млн. USD }\end{array}$ \\
\hline 1 & Китай & 4154 & 653259 \\
\hline 2 & США & 2176 & 552212 \\
\hline 3 & Росія & 1666 & 462841 \\
\hline 4 & Австралія & 1292 & 164280 \\
\hline 5 & Індія & 1038 & 142831 \\
\hline 6 & Саудівська Аравія & 694 & 319960 \\
\hline 7 & Індонезія & 679 & 104963 \\
\hline 8 & Бразилія & 506 & 114912 \\
\hline 9 & Канада & 490 & 183528 \\
\hline 10 & Іран & 461 & 151298 \\
\hline 11 & ПАР & 325 & 140920 \\
\hline 12 & Казахстан & 267 & 103476 \\
\hline 13 & Ірак & 238 & 119817 \\
\hline 14 & ОАС & 237 & 106167 \\
\hline 15 & Катар & 216 & 60963 \\
\hline 16 & Німеччина & 212 & 12462 \\
\hline 17 & Норвегія & 185 & 60794 \\
\hline 18 & Мексика & 172 & 78018 \\
\hline 19 & Кувейт & 151 & 73332 \\
\hline 20 & Алжир & 147 & 45312 \\
\hline 28 & Україна & 91,3 & 11780 \\
\hline
\end{tabular}

Примітка: не включаючи діаманти

Дані таблиці 1 свідчать, що нині лідируючі позиції за обсягами виробництва корисних копалин у світі займає Китай, США та Росія. Розподіл обсягів видобування корисних копалин у світі $\epsilon$ вкрай нерівномірний. Зокрема на 4 країни світу припадає $51 \%$ обсягів їх виробництва (рис. 1) [1]. 
Економічні науки: збірник наукових прачь Луиького національного технічного університету. Серія "Регіональна економіка". Випуск 17 (67). Редкол.: відп. ред. к.е.н., професор І.В. Кривов’язюк. Луцьк: ІВВ Луцького НТУ, 2020. 348 с.
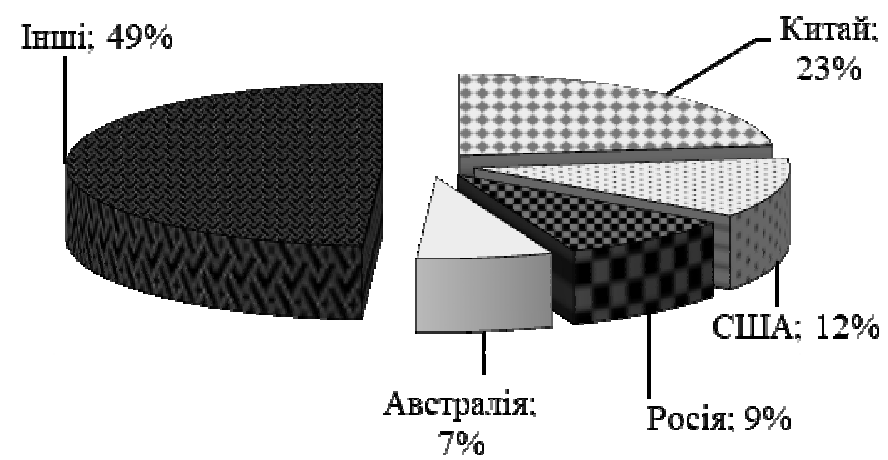

Рис. 1. Питома частка країн за обсягами виробництва корисних копалин у 2018 р., \%

При цьому лідером за обсягами виробництва корисних копалин виступає Китай, в якому виготовляється біля 23 \% їх світового обсягу. Другу позицію посідають США забезпечуючи $12 \%$ світового виробництва корисних копалин. Трійку лідерів зариває Росія, в якій виготовляється $9 \%$ від світового обсягу корисних копалин. Четверту позицію посідає Австралія в якій виготовляється біля $7 \%$ світового обсягу корисних копалин.

Україна у світовому рейтингу за обсягами виробництва корисних копалин посідає 28 місце. Таким чином, хоча Україна i не $\epsilon$ нині світовим лідером за обсягом виробництва корисних копалин, однак національна економіка на доволі високому рівні ними забезпечена.

В той же час за обсягами видобутку 8 видів корисних копалин Україна входить в топ-10 країн світу [1]:

- 2 місце у світі за обсягом видобування галію (2\% світового виробництва);

- 5 місце у світі за обсягом видобування германію (1\% світового виробництва);

- 6 місце у світі за обсягом видобування каоліну (5\% світового виробництва) та титану (7 \% світового виробництва);

- 7 місце у світі за обсягом видобування заліза $(2,6 \%$ 
Економічні науки: збірник наукових прачь Луиького національного технічного університету. Серія "Регіональна економіка". Випуск 17 (67). Редкол.: відп. ред. к.е.н., професор І.В. Кривов’язюк. Луцьк: ІВВ Луцького НТУ, 2020. 348 с.

світового виробництва);

- 9 місце у світі за обсягом видобування марганцю $(3,4 \%$ світового виробництва), урану (2\% світового виробництва) та графіту (1,4\% світового виробництва).

Однак важливо не лише володіти великими запасами природних ресурсів, але і бути спроможним належним чином управляти ними, ефективно їх використовувати. Для оцінювання якості управління нафтогазовим і гірничодобувним сектором економік країн світу використовують індекс управління ресурсами (The Resources Governance Index, RGI). B процесі розрахунку RGI до уваги береться певна кількість країн світу, яка займає лідируючі позиції за обсягами видобування нафтогазових та мінеральних ресурсів.

У 2017 р. індекс управління ресурсами в розрізі країн світу мав наступні значення (табл. 2) [2].

Таблиця 2

Рейтинг країн за індексом управління ресурсами

\begin{tabular}{|c|l|c|c|}
\hline $\begin{array}{c}\text { Місце в } \\
\text { рейтингу }\end{array}$ & \multicolumn{1}{|c|}{ Країни } & Вид ресурсів & $\begin{array}{c}\text { Значення } \\
\text { RGI, бали }\end{array}$ \\
\hline 1 & Норвегія & Нафта і газ & 86 \\
\hline 2 & Чилі & Мінеральні ресурси & 81 \\
\hline 3 & Великобританія & Нафта і газ & 77 \\
\hline 4 & Канада (Альберта) & Нафта і газ & 75 \\
\hline 5 & $\begin{array}{l}\text { США (Мексиканська } \\
\text { затока) }\end{array}$ & Нафта і газ & 74 \\
\hline 6 & Бразилія & Нафта і газ & 71 \\
\hline 7 & $\begin{array}{l}\text { Колумбія } \\
\text { (нафтогазовий сектор) }\end{array}$ & Нафта і газ & 71 \\
\hline 8 & Австралія (західна) & Мінеральні ресурси & 71 \\
\hline 9 & Індія & Нафта і газ & 70 \\
\hline 10 & $\begin{array}{l}\text { Колумбія } \\
\text { (гірничодобувний } \\
\text { сектор) }\end{array}$ & Мінеральні ресурси & 69 \\
\hline 44 & Україна & Нафта і газ & 49 \\
\hline 50 & Росія & Нафта і газ & 45 \\
\hline 89 & Еритрея & Мінеральні ресурси & 10 \\
\hline
\end{tabular}


Економічні науки: збірник наукових прачь Луиького національного технічного університету. Серія "Регіональна економіка". Випуск 17 (67). Редкол.: відп. ред. к.е.н., професор І.В. Кривов'язюк. Луиьк: ІВВ Луцького НТУ, 2020. 348 с.

Дані таблиця 2 свідчать, що найкраще управляють ресурсами у Норвегії (1 місце у рейтингу), в Чилі (2 місце у рейтингу) та Великобританії (3 місце у рейтингу). Україна за індексом управління посіла лише 44 місце серед 89 країн світу.

Для правильної інтерпретації значень індексу управління ресурсами, розглянемо їх можливі значення:

- >75 - добре. В країні діють закони і практичні заходи, які здатні забезпечити вигоди для населення в результаті видобутку корисних копалин, хоча можливі деякі витрати для суспільства;

-60-74 - задовільно. В країні $є$ ефективні політики і практичні заходи, але з ряду аспектів потрібні удосконалення. Вигоди для населення в результаті видобутку корисних копалин ймовірні, але можливі витрати для суспільства;

- 45-59 - слабко. В країні відмічаються як позитивні, так і проблематичні аспекти в сфері управління. Результати вказують на те, що природні ресурси можуть принести користь населенню, проте малоймовірно, що кінцеві вигоди будуть значними;

- 30-44 - погано. В країні прийняті мінімальні процедури і практичні заходи щодо управління ресурсами, проте більшість елементів, які забезпечують вигоди для населення відсутні;

- <30 - дуже погано. В країні практично відсутня база, яка дозволяла б забезпечувати вигоди для населення від видобутку корисних копалин. Існує велика ймовірність того, що вигоди залишаться в руках ряду компаній і представників державної еліти.

Таким чином, в Україні індекс управління ресурсами має доволі низьке значення (49 балів), що свідчить про те, що управління ресурсами здійснюється не на належному рівні. Використання природних ресурсів хоча і може принести вигоди населенню, але вони навряд чи будуть значними.

Отож, не зважаючи на те, що Україна доволі на високому рівні забезпечена природніми ресурсами, має місце низька ефективність управління ними. Це негативно відображається на можливостях забезпечення належного добробуту населення 
Економічні науки: збірник наукових прачь Луиького національного технічного університету. Серія "Регіональна економіка". Випуск 17 (67). Редкол.: відп. ред. к.е.н., професор І.В. Кривов'язюк. Луиьк: ІВВ Луцького НТУ, 2020. 348 с.

країни і є важливою проблемою для національної економіки.

Однак така ситуація не є якимось винятком із світової практики. Ще свого часу в одній 3 класичних робіт по даній проблемі «Natural resource abundance and economic growth» J. Sachsтаi A. Warner вказували на негативний взаємозв'язок між рівнем забезпеченості країни природними ресурсами і іï економічним зростанням [3].

В даній роботі в якості прикладу наводяться бідні природними ресурсами Нідерланди і Швейцарію XVII ст., які обігнали за показниками економічного зростання багаті природними ресурсами Росію та Іспанію. Стійка негативна кореляція простежується i в низьких темпах економічного зростання країн з достатком природних ресурсів: Лівія, Бахрейн, Саудівська Аравія [4].

Таким чином, хоча наявність в країні покладів нафти, газу або інших корисних копалин вартістю в мільярди доларів передбачає добробут іiі жителів, однак часто економіки країн 3 багатими природними ресурсами розвиваються повільніше, ніж економіки країн з бідними запасами корисних копалин. Одна 3 причин такої невідповідності - те, як здійснюється управління ресурсами.

Отож в Україні спостерігаються суттєві проблеми у сфері управління ресурсами. При цьому в національній економіці зазначена проблема носить довготривалий та системний характер. Ще свого часу Мартинюк I.В. у своїх дослідженнях наголошував на існуванні цілого ряду проблем у сфері державного регулювання природокористування в Україні [5]: відсутність досконалої нормативно-правової база, яка б належним чином регулювала процес природокористування; неналежне стимулювання до раціонального використання ресурсного потенціалу національної економіки; відсутність відповідності норм діючого законодавства в сфері природокористування міжнародним стандартам тощо. На жаль, i на сьогодні ці проблеми в національній економіці належним чином не вирішені.

Голян В., Кущ О. у своїх дослідженнях ставлять наступні 
Економічні науки: збірник наукових прачь Луиького національного технічного університету. Серія "Регіональна економіка". Випуск 17 (67). Редкол.: відп. ред. к.е.н., професор І.В. Кривов'язюк. Луиьк: ІВВ Луцького НТУ, 2020. 348 с.

невтішні діагнози економіці України [6; 7]:

- «голландська хвороба», яка передбачає, що національна економіка надмірно залежить від кон'юнктури світового ринку мінеральної сировини;

- «прокляття природних ресурсів», яке передбачає, що природні багатства не сприяють росту добробуту переважної частини населення.

«Голландська хвороба» $\mathrm{i}$ «прокляття природних ресурсів»- це феномени економічного розвитку країн, які володіють значними сировинними ресурсами. Для подолання цих хвороб необхідні ефективні інститути та відповідна структурна політика [8; 9].

Для підвищення якості управління ресурсами в Україні, забезпечення ефективного їх використання на благо суспільства потрібно вжити цілий ряд системних заходів: удосконалити нормативно-правову базу, яка б належним чином регулювала процес природокористування; забезпечити належне стимулювання до раціонального використання ресурсного потенціалу національної економіки; узгодити норми діючого законодавства в сфері природокористування 3 міжнародними стандартами; здійснити переорієнтацію національної економіки та структури вітчизняного експорту, зорієнтовану на підвищення частки продукції з високим рівнем доданої вартості тощо.

Висновки. Таким чином, в Україні має місце низька ефективність використання природних ресурсів, що зумовлено незадовільною якістю управління ними. Це негативно відображається на економічному розвитку національної економіки, іiі конкурентоспроможності на світовому ринку, провокує низький рівень життя українців тощо. Зазначена проблема вимагає негайного вирішення та вжиття цілого ряду системних заходів на всіх рівнях державного управління.

\section{Список бібліографічного опису}

1. Крупенина О. Мировая добыча полезных ископаемых. Украина в рейтинге добывающих стран. URL: https://biz.liga.net/ekonomika/all/opinion/mirovaya-dobycha-poleznyh-iskopaemyhukraina-v-reytinge-dobyvayuschih-stran (дата звернення 01.10.2020) 
Економічні науки: збірник наукових прачь Луиького національного технічного університету. Серія "Регіональна економіка". Випуск 17 (67). Редкол.: відп. ред. к.е.н., професор І.В. Кривов’язюк. Луцьк: ІВВ Луцького НТУ, 2020. 348 с.

2. Индекс управления ресурсами 2017. URL: https://resourcegovernance.org/sites/default/files/documents/2017-resourcegovernance-index-russian_0.pdf (дата звернення 02.10.2020)

3. Sachs J. and Warner A. The curse of natural resources, European Economic Review. 2001. 827-38.

4. Шалаева А.А. Влияние наличия природных ресурсов на экономический рост стран. URL: file:///C:/Users/Oksana/Downloads/vliyanienalichiya-prirodnyh-resursov-na-ekonomicheskiy-rost-stran.pdf (дата звернення 05.10.2020)

5. Мартинюк I.B. Державне регулювання природокористування як елемент ефективного розвитку національної економіки в умовах євроінтеграції. Вісник сочіально-економічних досліджень. 2011, Вип. 3 (43). C. 361-366.

6. Голян В.А. Економічна криза в Україні: феномен «голландської хвороби» те рецедив «ресурсного прокляття». Економіка та держава. 2016. № 7, С. 4-15.

7. Кущ О.З країни, що виробляє ракети й літаки, Україна перетворилися на країну-олійницю та країну - кукурудзяне поле. URL: https://ua.112.ua/mnenie/z-krainy-shcho-vyrobliaie-rakety-i-litaky-ukrainaperetvorylysia-na-krainu-oliinytsiu-i-krainu-kukurudziane-pole-549924.html (дата звернення 08.10.2020)

8. Прудникова О.А. Проблема «проклятия природных ресурсов» и ее влияние на экономический рост. URL: file:///C:/Users/Oksana/Downloads/problema-proklyatiya-prirodnyh-resursov-i-eevliyanie-na-ekonomicheskiy-rost.pdf (дата звернення 10.10.2020).

9. Червяков I.M. Фактори уповільнення економічного зростання: «голландська хвороба», «прокляття ресурсів» та шляхи їх подолання. URL: http://dspace.nbuv.gov.ua/bitstream/handle/123456789/94801/58-

Chervyakov.pdf?sequence=1 (дата звернення 09.10.2020).

\section{References}

1. Krupenina O. Mirovaja dobycha poleznyh iskopaemyh. Ukraina v rejtinge dobyvajushih stran. Available at: https://biz.liga.net/ekonomika/all/opinion/mirovaya-dobycha-poleznyh-iskopaemyhukraina-v-reytinge-dobyvayuschih-stran (accessed 01.10.2020) [In Russian]

2. Indeks upravlenija resursami 2017. Available at: https://resourcegovernance.org/sites/default/files/documents/2017-resourcegovernance-index-russian_0.pdf (accessed 02.10.2020) [In Russian]

3. Sachs J. and Warner A. The curse of natural resources, European Economic Review, 2001, 827 p.

4. Shalaeva A.A. Vlijanie nalichija prirodnyh resursov na jekonomicheskij rost stran. Available at: file://C:/Users/Oksana/Downloads/vliyanie-nalichiyaprirodnyh-resursov-na-ekonomicheskiy-rost-stran.pdf (accessed 05.10.2020) [In Russian]

5. Martyniuk I.V. Derzhavne rehuliuvannia pryrodokorystuvannia yak 
Економічні науки: збірник наукових прачь Луиького національного технічного університету. Серія "Регіональна економіка". Випуск 17 (67). Редкол.: відп. ред. к.е.н., професор І.В. Кривов’язюк. Луцьк: ІВВ Луцького НТУ, 2020. 348 с.

element efektyvnoho rozvytku natsionalnoi ekonomiky v umovakh yevrointehratsii. Visnyk sotsialno-ekonomichnykh doslidzhen, 2011, no 3 (43), pp. 361-366 [In Ukrainian]

6. Holian V.A. Ekonomichna kryza v Ukraini: fenomen «hollandskoi khvoroby» te retsedyv «resursnoho prokliattia». Ekonomika ta derzhava, 2016, no 7, pp. 4-15 [In Ukrainian]

7. Kushch O.Z krainy, shcho vyrobliaie rakety y litaky, Ukraina peretvorylysia na krainu-oliinytsiu ta krainu - kukurudziane pole. Available at: https://ua.112.ua/mnenie/z-krainy-shcho-vyrobliaie-rakety-i-litaky-ukrainaperetvorylysia-na-krainu-oliinytsiu-i-krainu-kukurudziane-pole-549924.html (accessed 08.10.2020) [In Ukrainian]

8. Prudnikova O.A. Problema "prokljatija prirodnyh resursov" i ee vlijanie na jekonomicheskij rost. Available at: file://C:/Users/Oksana/Downloads/problemaproklyatiya-prirodnyh-resursov-i-ee-vliyanie-na-ekonomicheskiy-rost.pdf (accessed 10.10.2020). [In Russian]

9. Cherviakov I.M. Faktory upovilnennia ekonomichnoho zrostannia: "hollandska khvoroba", "prokliattia resursiv" ta shliakhy yikh podolannia. Available at: http://dspace.nbuv.gov.ua/bitstream/handle/123456789/94801/58Chervyakov.pdf?sequence $=1$ (accessed 09.10.2020) [In Ukrainian]. 